\title{
Icons: identifying continence options after stroke trial: utility of a logic model in the design and implementation of a process evaluation
}

Lois Thomas ${ }^{1 *}$, Christopher Burton², Beverley French', Michael Leathley ${ }^{1}$, Denise Forshaw ${ }^{1}$, Christopher Sutton ${ }^{1}$, Brenda Roe ${ }^{3}$, Brigit Chesworth ${ }^{1}$, Caroline Watkins ${ }^{1}$

From 2nd Clinical Trials Methodology Conference: Methodology Matters

Edinburgh, UK. 18-19 November 2013

\section{Background}

ICONS is a cluster randomised controlled pilot trial designed to provide preliminary evidence of the effectiveness of a systematic voiding programme (SVP) for the management of continence after stroke. Stroke services were randomised to receive the SVP, the SVP plus supported implementation, or usual care. Process evaluations are designed to evaluate fidelity and provide explanatory evidence around trial outcomes; these need to be underpinned by a theoretical framework to explain linkages between intervention processes and outcomes.

\section{Process evaluation}

We conducted an evaluation to describe SVP implementation and assist in explaining intervention outcomes. Reflecting best practice in complex intervention research, we developed a logic model to underpin the evaluation representing practitioners' implementation activities. To increase explanatory power of the model, we synthesised principles from theoretical frameworks underpinning the study (e.g. the Normalisation Process Model) into mechanisms of action to explain conditions necessary for activities to impact on outcomes. Mechanisms were:

- Understanding and agreeing: conceptual work associated with the SVP, e.g. increasing awareness.

- Driving and aligning: organising systems or processes to align and drive new practice.

- Building and supporting: enacting the SVP.

- Learning and evaluation: reflecting on performance and progress.

${ }^{1}$ University of Central Lancashire, Preston, UK

Full list of author information is available at the end of the article

\section{Findings}

We will discuss the utility of the logic model in explaining conditions necessary for the intervention to work, the success of implementation strategies adopted and variations in patient outcome across trial arms. We will also consider the challenges of synthesising across multiple data sources to understand variation in intervention delivery, maintenance and outcome in cluster trials.

\section{Authors' details}

'University of Central Lancashire, Preston, UK. ${ }^{2}$ Bangor University, Bangor, UK. ${ }^{3}$ Edge Hill University, Ormskirk, UK.

Published: 29 November 2013

\section{doi:10.1186/1745-6215-14-S1-090}

Cite this article as: Thomas et al.: Icons: identifying continence options after stroke trial: utility of a logic model in the design and implementation of a process evaluation. Trials 2013 14(Suppl 1):090.

Submit your next manuscript to BioMed Central and take full advantage of:

- Convenient online submission

- Thorough peer review

- No space constraints or color figure charges

- Immediate publication on acceptance

- Inclusion in PubMed, CAS, Scopus and Google Scholar

- Research which is freely available for redistribution 